\title{
An Evaluation Of Factors Influencing Pension Managers' Investment Decisions In Kenya
}

Lucy Jepchoge Rono, MOI University, Kenya

\begin{abstract}
This study focused on the analysis of factors influencing pension fund managers' investment decisions. The objectives of the study were to identify investment options available to pension fund managers, identify factors that are considered by fund managers when making investment decisions and identify challenges faced by fund managers in making investment decisions. Three representatives from each of the twelve registered fund managers completed the study questionnaire. The questionnaire was administered through the drop and pick later method. Data was analyzed using SPSS (Statistical Package for Social Sciences) and summarized using descriptive statistics such as mean, standard deviation, frequencies, percentages. The study found out that returns, investment risks and trends in interest rates were the most important factors affecting pension managers' investment decisions. Decision-making preferences, investment portfolio, past performance and legal framework were rated as less important. Consistency and return maximization in the rate of returns (sustainable long term returns), prevailing economic and political situations-inflation, global markets which determines key indicators like interest rates/ exchange and risk profile of the scheme investment (risk assessment of the board of trustees) in that order are also important qualitative factors in decision making for pension fund investment. The research also found out that few investment avenues/ vehicles, bureaucracy in consultations with trustees and unpredictable/ turbulent and dynamic market situations in that order are the major challenges facing fund managers investing pension funds. The researcher identified a need for a portfolio that will give higher returns. There is also need to harmonize all regulations relating to pensions in order to create efficiency and avoid confusion. The research also recommends that RBA benchmarks with the world best in order to help the sector to achieve growth. The promotion of retirement funds and regulatory functions should be separated to avoid conflict of interest in the two roles.
\end{abstract}

\section{List Of Abbreviations}

NSSF: National Social Security Fund

RBA: Retirement Benefits Authority

KRA: Kenya Revenue Authority

SPSS: Statistical Package For Social Sciences

\section{CHAPTER ONE}

INTRODUCTION

\subsection{Background of the study}

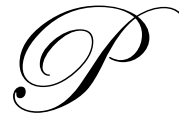

ension is a benefit promised to an employee by an employer during employment and is payable on leaving or retiring from the employer's service. In the developed countries, pension plans are established and managed through creation of trust. In many cases, the fund is invested by the employer and pension is payable from the recurrent revenue of the employer. In cases which are semi independent, pensions are managed by insurance companies under the concept of guaranteed fund. Employees lately prefer the 
later kind of pension because of its independence from the employer.

Following the historic case of Enron Ltd in the United States of America (2001) where the pension fund was invested substantially in the employer's stock, it became, more necessary to have independent pension fund management and custodial services away from employers. In this case the employer had unlimited access to the pension fund and was totally invested in the group of companies owned by the employer thus pension funds were lost in these cases due to lack of independence from the employer. To achieve the independent management of pension schemes away from employers it became necessary for legislation, which devolves the responsibilities of pension funds management to trustees from that of employers.

\section{Pension Funds In Kenya}

In Kenya, employers or Trust Corporations set up pension funds under irrevocable trusts. This is done in accordance with following Acts of Parliament: Trustees (Perpetual Succession) Act Cap 164; Trustees Act Cap 167; Public Trustee Act Cap 168; Perpetuities and Accumulation Act 1984; Income Tax Act Cap 487 and Retirement Benefit Act, (1997). The Retirement Benefit Act, (1997) gave rise to the development of the Retirement Benefit Regulation for occupational schemes 2001. This became operational on $8^{\text {th }}$ October, 2001. The regulations are intended to achieve separation of pension funds from the employer's funds. This is because in the past employers had unlimited access to the pension funds and would use it to improve their cash flows in the company. Some of the cases include Railway Corporation, Postal Corporation and the University of Nairobi.

The investment of the pension fund is the responsibility of the pension trustees. The Retirement Benefit Regulations (occupational retirement benefit schemes) 2001 provides an investment guideline under section 38. Prudent investment of pension funds is absolutely necessary in order to safeguard the pension fund member's interest. This should also enable trustees to achieve their role in discharging their responsibilities to members leaving the employer's service and/or retiring at old age.

The fund managers investing in pension funds are governed by the Retirement Benefits Act, (1997). This Act has specific guidelines on the limits of exposures for each asset class it trades in. When the Retirement Benefits Act, (1997) was set up, it required all pension schemes to have a prudent investment policy in line with the investment guidelines provided there in and to appoint a fund manager to direct and assure trustees in investing pension funds. The question is how a fund invested by an insurance company is to be treated. From then on, Insurance companies have set up separate subsidiary companies to meet this legal requirement. However, on the actual investment, they follow the requirements of the Insurance Act.

Since the above developments are very recent, they have changed the way pension funds operate. It is therefore important to bring to light the factors influencing fund managers investment to facilitate knowledge for argument to invest with fund managers so as to harmonize the operation of pension funds in Kenya. The changes in the regulatory environment also mean that the sector has to change significantly to comply with the new requirements.

\subsection{Statement of the problem}

The market for private pension is very young in Kenya. A recent survey revealed lack of private pensioners in Kenya (RBA News, 2002). This was mainly because none of the members had reached retirement age at the time of the study. This indicates that the private pension is relatively new in Kenya and therefore it needs to be studied thoroughly as it develops. Members to these funds need a lot of transparency, which was found lacking in the public pension schemes (RBA News 2002). Previous research indicates that the pension industry is a major component of the financial sector and needs to be thoroughly studied (Mogera, 1999). The retirement benefit industry has continued on a growth path since coming into effect of the Retirement Benefits Act in 2000 (RBA Annual Report, 2003).

One key aspect in the management of pension funds is investment decisions. Pension trustees are in a dilemma as to which way to go in investing pension funds to optimize returns without taking a lot of risk. The 
question that is frequently asked by trustees of pension funds is whether it is better to invest with fund managers or insurance companies. It is therefore vital to extensively study, analyze the present gaps in order to assist pension fund trustees and the government of Kenya to realize better returns. This research intended to evaluate the factors influencing pension fund managers' investment decisions.

\subsection{Objectives of the study}

The purpose of this research was to evaluate the factors influencing pension fund managers' investment decisions. The specific objectives were to:

1. To identify investment options available to pension fund managers

2. To identify factors that are considered by pension fund managers when making investment decisions

3. To identify challenges faced by fund managers in making investment decisions

\section{$1.4 \quad$ Research Questions}

This research aimed at addressing the following questions:

1. What are the available investment options in Kenya?

2. What factors influence pension fund managers in making investment decisions?

3. What challenges are the fund managers facing in making their decisions?

\subsection{Importance of the study}

The results of this study will enable Insurance Companies and fund managers to formulate appropriate strategies in the investment of pension schemes in order to tap the their full potential in growing the pension market in a liberalized economy. This will in turn create a competitive edge.

The fund managers will be enabled to focus on better performing sectors of the economy and formulate appropriate investment guidelines for their pension portfolios

The Ministry of Finance and the Government will use the results to implement the necessary corrective measures to bridge the existing gaps and enhance the expected performance of the pension funds. This will in effect result in the growth and safety of pension funds and will create confidence in the industry; it will attract potential savers, corporations and individuals, the public and private sector including the informal and semi-informal sector. This will enhance availability of long-term savings in addition to eradicating poverty at old age.

Trustees of pension funds who make direct investment decisions on behalf of the members and beneficiaries within the investment guidelines will find the results a resource and hence discharge their duties more efficiently

The policing function of the Retirement Benefit Authority will be felt especially by the funds, which are non-compliant.

This study will also contribute to knowledge in the academic fields, research institutions, learning institutions and individuals. The findings will also be beneficial to pension administrators in advising pension trustees to make informed decisions on investment of pension funds.

Finally, the findings of this study will be of good value to potential local and international investors considering possibility of setting up fund management and insurance companies in Kenya. 


\subsection{Scope of the study}

The fund management and insurance companies are geographically based in various towns spread throughout Kenya. However the research studied the fund managers based in Nairobi only while those located in other parts of the country were not considered.

\section{CHAPTER TWO}

\section{LITERATURE REVIEW}

\subsection{Introduction to Literature Review}

This chapter expounds on the content discussed in chapter one. It also discusses literature reviewed on available opportunities of investing pension funds in any economy. For the Kenyan scenario the review concentrated on the money market, real estate, stocks, government securities stocks and offshore investment. The conceptual framework and a review of past studies done in this area are included. The literature review was conducted from textbooks, journals, periodicals, seminar material, past research studies and internet search.

\subsection{Conceptual Framework}

The pension fund manager is faced with a decision of whether to invest in the money market, real estate, government securities, stocks and offshore investment. The total investment was treated as the dependent variable. This was considered in relation to independent variables considered in investment decision making which include; returns, risk, amount involved, preference of decision makers, investment ceiling and investment portfolios. These were also be operationalised by considering the proportion of investments in money market, real estate, government securities, stocks and offshore investment as the independent variables. This was diagrammatically represented as shown in Figure 1.

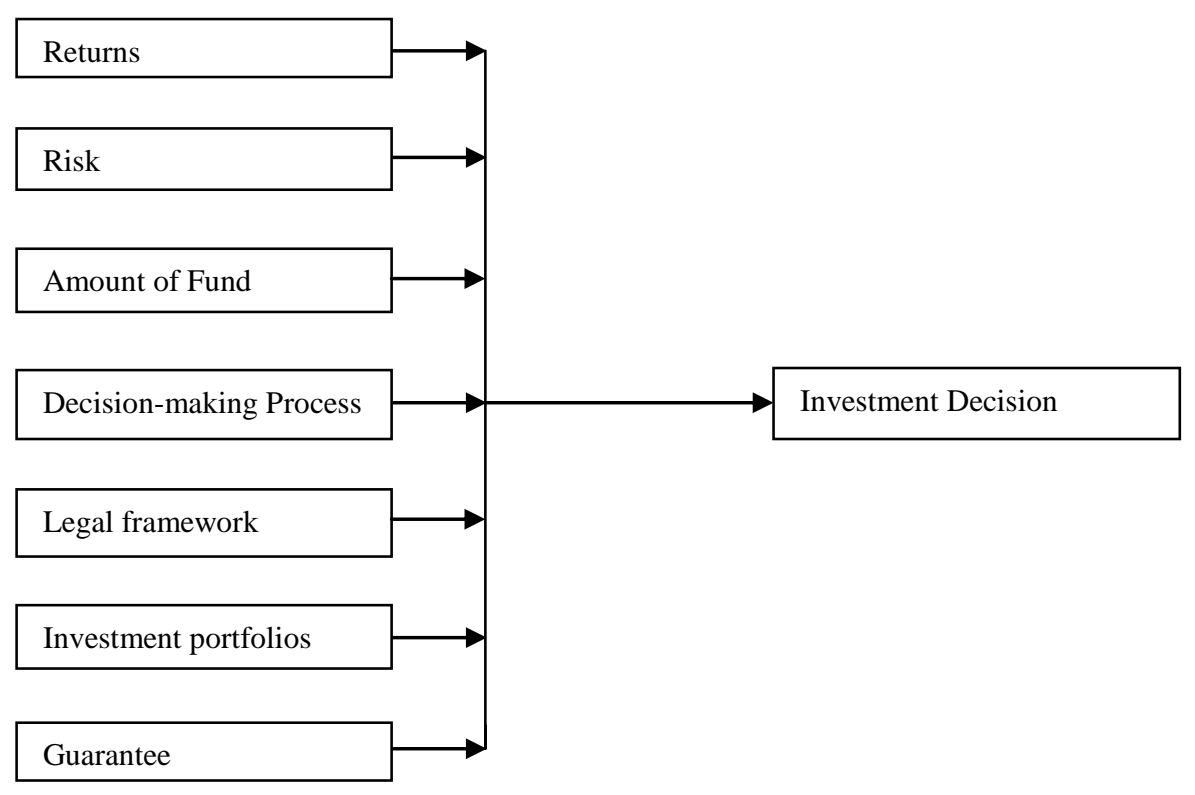

(Independent Variables)

(Dependent Variable)

Figure 1: Conceptual Framework 


\section{Pensioners Expectations and Current and Past Practices}

Pension is a sum of money paid regularly by the state or by trustees to an employee upon normal or illhealth retirement. Pensioners need a good return on their investments; pension funds normally thrive in an environment of low inflation due to stable monetary policies. However, development in the capital and money markets have brought new perspectives to this kind of thinking. Retirement Benefits Authority also intend to educate retirees as to how too apply their retirement benefits. (RBA News, 2002).

Kenyans are continuously being educated on the need for saving for tomorrow. Saving begins by investing well before the need for the money, arises. Investing of earnings leads to the growth of money. To be able to achieve long-term goals in life many people save towards their old age when they will be less active to be able to make the money There are various ways of saving towards retirement such as through savings in a bank account, purchasing a life insurance policy,, setting up a pension fund either on individual basis or through a group arrangement for those in formal employment (MicroSave Africa, 2000)..

Kenya being a British colony has adopted the British system in almost all spheres of lifestyle including the way of investing their money. An example is the formation of the National Social Security Fund (NSSF), which is similar to the state pensions of the United Kingdom (UK). In addition the setting up of occupational pension funds in Kenya is borrowed from the UK (Mghali, 2003).

In Britain, the first occupational pension scheme was established by the government as an employer trying to assist and reward a good employee when he was no longer fit for service. At the beginning, the benefits were provided out of the current contributions paid by the employer and the existing employees so that no money was to be invested. This worked well when dealing with highly paid employees who were paid more than they required satisfying their basic needs. The system was unsatisfactory for the lowly- paid who were the majority.

The first superannuating fund was established in the UK during the $16^{\text {th }}$ century for the civil servants under London customs and excise officers (Kluwer, 1996). It was financed on a pay-as-you-go basis, which involves the setting up of an investment fund into which contributions by employer and employee. Members then received a pension on retirement, which was paid out of the fund (Kluwer, 1996). Pension funds in Kenya were set up under irrevocable trusts by employers or Trust Corporations in accordance with Trustees (Perpetual Succession) Act Cap 164, Trustees Act Cap 167, Public Trustee Act Cap 168, Perpetuities and Accumulation Act, (1984), Income Tax Act Cap 470 and Retirement Benefit Act, (1997).

According to Appleby (1994), many firms conduct pension schemes either as separate trust funds where firm's contributions (and the employee's contributions in a contributory scheme) are invested and the scheme controlled by trustees or life office schemes where a contract is made with a life assurance officer. In his study Mghali (2003) concluded that firms should conduct pension schemes where the employer contributes a certain percentage together with the employee contribution. These funds should then be invested and with trustees being in control the fund. In his study on National Social Security Fund (NSSF) Mugweru (2001) recommended that investment department at NSSF should consist of professionals who adhere to proper investment policies and procedures. Kluwer (1996) suggest that the reason for a direct invested fund is to prepare that fund to meet its liabilities. Fund managers and insurance companies in Kenya carry out investments of pension funds in various ways. According to the Insurance Act Chapter 487 of the laws of Kenya, long-term business, which includes life and pension investment, they have to set up a statutory fund separate from the short-term business.

The assets in the statutory fund so set up is required to be vested in trustees but kept in the name of the insurance company. The long-term nature of pension schemes has given rise to specific needs in the investment of pension funds. First is the need for stable returns as opposed to highest returns. Secondly there is need for security or safety of the fund as opposed to the best possible return. Four broad ways exist on how these funds may be invested; Insurance policies, pooled funds, self-investment and offshore investment. By paying a premium to the insurance company who guarantees a benefit at retirement. The insurance company takes the risk of investment; the premium is usually high resulting in unnecessary high cost of pension. This method has largely been discarded, as it is not cost effective. 
In the mid 90s the insurance companies started the idea of pooled funds, which operated more like a savings account. The pension contributions were paid into a pool invested by the insurance company. At the end of every year, a rate is declared which is used to credit interest into the pension fund.

The choice of channel of pension fund investment is the responsibility of pension fund trustees. However, the law of trusts and the Retirement Benefits Act (1997) allows the pension trustees to delegate this duty to a fund manager without abdicating the ownership of the fund. It is more important for the fund manager to get the strategy right to ensure this complies with the long-term nature of the fund's liabilities. It is for this reason that pension trustees take an extra precaution of inviting other professionals such as the actuary, auditor, administrator, legal advisor and insurers in addition to trustees opinions.

As Trustees make the choice to delegate their investment responsibility to some outside source, Insurance Companies come into the reckoning as leading providers since they have unparalleled wealth of knowledge and experience.

The structure of Insurance Company is in two parts, the Short Term Business and the Long Term Business. The short term business division of an Insurance company comprises of annual covers ranging from fire \& perils, motor insurance, burglary, workmen's compensation act, medical Insurance, professional indemnity among others. The long-term side of Insurance business encompasses life insurance and pension fund management.

Insurance companies pension fund investment receive full time attention with a general manager top level investment expert leading an investment committee in scanning available opportunities in the market to buy and sell.

The success of a pension fund is determined by the investment policy. The investment policy used by Insurance companies is guided by Section 50 of the Insurance Act cap 487 of the laws of Kenya. This provides a general maximum level of exposure of each asset class. This guide is diagrammatically represented in Table 1.

Table 1: Extract of section 50 of insurance act cap 487 (revised 2004)

\begin{tabular}{|l|l|c|}
\hline & \multicolumn{1}{|c|}{ Category of Assets } & $\begin{array}{c}\text { Maximum percentage of Exposure of } \\
\text { total asset of pension fund. }\end{array}$ \\
\hline $\mathbf{1}$ & Government securities mortgages & $20 \%$ \\
\hline $\mathbf{2}$ & $\begin{array}{l}\text { Unencumbered unmovable property in Kenya } \\
\text { Debentures secured by a mortgage or unencumbered immovable property in } \\
\text { Kenya Commercial papers, preference shares loan or life assurance policies }\end{array}$ & $20 \%$ \\
\hline $\mathbf{3}$ & Deposits in banks or financial institutions licensed under balancing Act & $5 \%$ \\
\hline $\mathbf{4}$ & $\begin{array}{l}\text { Promising notes bills of exchange or other instruments issued by accompany } \\
\text { incorporated under the companies Act }\end{array}$ & $5 \%$ \\
\hline
\end{tabular}

Source: Insurance Act Cap 487 (Revised 2004)

The Insurance companies have developed records a statutory fund known as a Retirement Benefit Fund as directed by the commission of Insurance through his detailed circular No. CI/01/02 dated January 2004.

This ensures that the pension funds will remain independent of the long-term life funds, as various trustees legally owe them.

The insurance companies operate pooled funds, which guarantee a minimum return of about 3 to $5 \%$ ranging from one insurance company to another. The pooled funds are invested as per section 50 of the insurance Act and interest net of all administration costs is declared at the end of the financial year. This concept of guarantee of return sells very well to pension funds at start up stage so that the trustees do not take too much risk if the economy performs poorly. In the last six years the average rate of interest declared by top on the list insurance companies is about $15 \%$ as demonstrated in Table 2. 
Table 2: Track Record of Insurance Company's Pooled Funds

(Historical Investment Performance For The Last Seven Years)

\begin{tabular}{|l|c|c|c|c|c|c|c|}
\hline Insurance company & $\mathbf{1 9 9 8}$ & $\mathbf{1 9 9 9}$ & $\mathbf{2 0 0 0}$ & $\mathbf{2 0 0 1}$ & $\mathbf{2 0 0 2}$ & $\mathbf{2 0 0 3}$ & $\mathbf{2 0 0 4}$ \\
\hline ICEA & $21 \%$ & $20.5 \%$ & $19.5 \%$ & $12.5 \%$ & $10 \%$ & $10 \%$ & $8.5 \%$ \\
\hline Heritage A.I.I & $19 \%$ & $21 \%$ & $18 \%$ & $10 \%$ & $11 \%$ & $10.5 \%$ & $10.5 \%$ \\
\hline Kenindia & $18 \%$ & $21 \%$ & $18 \%$ & $12.5 \%$ & $11.5 \%$ & $10.5 \%$ & $10.5 \%$ \\
\hline British American & $19.5 \%$ & $20 \%$ & $18 \%$ & $12 \%$ & $10 \%$ & $9 \%$ & $8 \%$ \\
\hline Alico & $21 \%$ & $21 \%$ & $22.5 \%$ & $11.5 \%$ & $11.5 \%$ & $11.5 \%$ & $9 \%$ \\
\hline Mercantile Life & $18.5 \%$ & $20 \%$ & 18.55 & $10 \%$ & $10 \% \wedge$ & $10 \%$ & $10 \%$ \\
\hline Jubilee & $20.25 \%$ & $20.25 \%$ & $23 \%$ & $13 \%$ & $12 \%$ & $12 \%$ & $11.75 \%$ \\
\hline Pan Africa & $21 \%$ & $20 \%$ & $18 \%$ & $5 \%$ & $7 \%$ & $10 \%$ & $9 \%$ \\
\hline Madison & $18 \%$ & $18 \%$ & $17.75 \%$ & $7.5 \%$ & $7.5 \%$ & 7.55 & $6 \%$ \\
\hline
\end{tabular}

Source: Researcher (2005)

\section{Role of Fund Managers in Pension Funds}

Apart from using Insurance Companies to invest pension funds, pension fund trustees may elect to invest directly. Fortunately the law allows the trustees to delegate to fund managers who are governed by the Retirement Benefits Act (1997) Capital Markets Authority, and Banking Act among others.

The fund management market in Kenya in pension investment is a fairly recent development. Owing to the increasing importance attached to pension funds world wide to spur economic development through mobilization of domestic savings and a source of long term credit for both government and private sector, the number of finance in his budget speech for year 2004/2005 reiterated the role played by retirement benefits sector and Institutional investors such as fund managers. In Business week, dated $20^{\text {th }}$ May 1997, financial experts agreed that the retirement benefit sector controls assets in excess of $30 \%$ of Kenya's Gross Domestic Product (GDP).

The custodian role in the overall set up of a fund management company has created 'Chinese Wall' to ensure that funds are directly deposited into the fund account for each pension fund. This is in link with the requirement of the Retirement Benefits Act (1997). The performance of fund management companies over the past years is in line with the economic performance.

Kiptanui (2003) in his speech to pension trustees in a seminar the Retirement Benefits Act does not direct pension funds where to invest the funds but only gives broad guidelines as to how pension funds are to be invested. The fund managers appointed by the trustees are guided in their strategy formulation. A summary of the guideline is shown in Table 3.

Table 3: Summary of the Benefit Act (1997) Investment Guidelines

\begin{tabular}{|c|l|c|}
\hline Item & \multicolumn{1}{|c|}{ Categories of Assets } & Maximum percentages (\%) of total asset value of fund \\
\hline 1 & Cash & $5 \%$ \\
\hline 2 & Fixed Deposit & $30 \%$ \\
\hline 3 & Commercial Paper & $15 \%$ \\
\hline 4 & Kenya Government Securities & $70 \%$ \\
\hline 5 & Preference Shares and Ordinary Shares & $70 \%$ \\
\hline 6 & Unquoted Shares of Companies for Orphaned in Kenya & $5 \%$ \\
\hline 7 & Off-shares Investment & $15 \%$ \\
\hline 8 & Immovable Property & $30 \%$ \\
\hline 9 & Guarantied Funds & $100 \%$ \\
\hline 10 & Any other Assets & $5 \%$ \\
\hline
\end{tabular}

Source: Retirement Benefits Act (1997) 


\section{Investment Considerations}

Pension fund trustees are bestowed with various responsibilities including the power to produce income by means of proper investment (Trustee Act Cap 167 ) and to have a prudent investment policy ( Retirement Benefit Act 1997 ). To achieve a good investment performance, pension trustees who are more often than not, not investment gurus, will delegate this responsibility to professional finance experts either fund managers or insurance companies. Fortune (2004), insists that investment is like exploring for gold. In its natural state deep in the ground gold is un-glittery stuff. This precious ore, rubbed dull by the earth around it is easy to miss.

Returns. From his study on investment performance of pension funds, Mogera (1999) found that choosing a fund manager is not an easy task for pension trustees. He explained that using past performance is not necessarily an accurate guide to future returns. This leaves a gap to be explored whether there are other measures, or considerations to be used in choosing a fund manager to invest pension funds. However, returns are linked to risks. The old adage goes that 'the higher the risk the higher the return. The key issue that any investment have to take into consideration the risk return trade off. For pension funds the focus is more on return stability than the rate of return. In this case pension funds will rather go for relatively low rates of returns that are guaranteed than go for higher returns that are not guaranteed.

Risks. Marwa's (1992) findings in his study on actuarial costing methods used in insured pension schemes in Kenya, found that successful pension funds investment should be one whose returns justify the risk taken. This means that one of the factors to be considered in making investment decisions is risk. But there is a gap that needs to be addressed from the aspect of risk, and that in the risk of capital loss in a pension fund, how would pension trustees explain to beneficiaries if there were negative returns?. Risk is a major concern in pension as wherever there is an expected return there is a risk as the old adage goes, 'nothing risked nothing gained'. The objective of any fund managers is to balance the risk to ensure optimal return.

Any investor is guided by the utility got from taking a risk. For instance, there are three levels of risk profiles; one is risk averse where risk is avoided as much as possible, the other one is a risk taker who takes high risks and the other profile is risk neutral who is not risk conscious. Individuals or entities with the key aim of maximizing utility adopt any of the three profiles. Deloitte, (2004), suggest a three-staged approach to risk management. These stages include: formulating a risk management strategy by consulting well informed industry players, testing and challenging the strategy by assessing the risk both in narrow and broad perspectives and determining the risk return trade off which identity's the level of risk tolerance for the entity.

Diversification. Diversification calls for spread of investment between asset classes or within asset classes. The focus by Retirement Benefits Act (1997) is on diversification hence the implementation of the investment guideline as shown in Table 3. Grubel (1968) showed the effects of diversification using market indices in 11 countries urging that US investors could gain from such international diversifications. American Economic Review (1970) reported an evaluation of benefits of diversification across national borders using data from 1051-1967. The findings indicate that the investment in US and Japan stock would have been 50\%- 70\% of optimal portfolios largely because of the negative correlations during that time between stock market indices in the two lands

Plager (2003) reported in an investment survey that pension funds in UK are seeking greater diversity within bonds moving into corporate and international index linked bonds. The survey also showed fewer areas of involvement in investment in 2003 compared to 2002 . This is partly explained by investment managers' slyness to publish their results. Coomber (2003) studied investment management industry and concluded that investment consulting fraternity need to be published. It calls for a further investigation to shed light on why the fund managers withhold their results. This study will endeavor to investigate the operations of fund management companies in pursuit of getting answers to this question.

Asset Classes. To achieve diversification, the fund managers' strategy is to invest in various asset classes within provision of the law. The main asset classes to be considered in this research are; cash, bonds, equities, property, offshore investment, money market, government securities. 


\subsection{Conclusions On Literature Review and Information Gaps Identified}

The literature review reveals that pension funds are on a growth trend in Kenya. This is especially so for private and independent pension schemes where an RBA study found few or no pensioners as the scheme members had not reached retirement age (RBA News, 2002). It follows that this is almost an emerging sector and it needs to be studied thoroughly to help fuel and demystify the growth.

The effects of the Retirement Benefits Act (1997) including the guidelines on investment on various Asset classes need to be studied to evaluate the fund manager's leeway within the set guidelines. Plager (2003) and Coomber (2003) both identified the need for investment consulting fraternity to be published. Mogera (1999) identified the difficulty faced by pension trustees in choosing a fund manager. Marwa (1992) indicates a gap in terms of the difficulties that could face trustees in explaining negative returns to beneficiaries and therefore the need to insulate such funds from capital loss.

The recent case of Enron where pension funds were substantially invested in the stocks of related companies highlights the risk of employer managed pension schemes. Issues of governance in this case were related to local cases such as Kenya Railway and University of Nairobi pension schemes, which had faced similar challenges. The need for more information and transparency in the running of pension scheme appears to be definite.

Many of the studies quoted are foreign and there is need to evaluate whether the foreign findings are applicable in Kenya. Still, while some aspects may have been studied locally, there is need for up to date information to enhance the currency of that information.

\section{CHAPTER THREE RESEARCH METHODOLOGY}

\subsection{Introduction to Research Design and Methodology}

This chapter shows how the data was collected to address the objectives in chapter one and fill the research gaps in chapter two. It is organized into the research design, target population, sample frame and sampling techniques, data collection, and data analysis.

\subsection{Research Design}

This study was exploratory and descriptive in nature and the researcher used survey method. Mugenda \& Mugenda (1999) notes that a survey research attempts to collect data from members of a population and describes existing phenomena by asking individuals about their perception, attitudes behavior or values. Moreover, it explores the existing status of two or more variables at a given point in time. Primary data collected from such a population or census is more reliable and up-to-date and hence the choice of this method.

The descriptive research was meant to enhance a systematic description that is as accurate, valid and reliable as possible regarding the responses on the investment options available to pension schemes and the factors considered in selecting various combinations.

\subsection{Target Population}

The target population, which the research covered, consists of all the 11 fund managers registered with the Retirement Benefit Authority RBA (Appendix C attached).

\subsection{The Sample and Sampling technique:}

This was a census study, as all the 11 fund managers in the population were studied. This meant that each of the registered fund managers were approached to participate in the study. The researcher approached at least three senior officers in each fund management firm. These officers were those who are actively involved in making investment decisions. 


\subsection{Data Collection Methods}

The study employed various survey instruments for data collection mainly:

A simple structured questionnaire was administered to the investment managers of the pension funds. The instrument was consisted of two parts. Part A consisted of items eliciting general information about the company and part B consisted of items relating to the study objectives. The instrument consisted of closed and open-ended questions. The questionnaire helped capture ways of operations, management style, level of expertise, resource availability such as technology, which touches on investment decision-making, and choice of options of investing pension funds.

The choice of a structured questionnaire was due to its ease of administration, analysis and time saving. Reason for e-mailing was that it was faster to tabulate and edit the responses through the electronic media and it is also cheaper and it reduces bias. Closed ended questions in the questionnaire helped to standardize and quantify responses from the research. The open-ended questions in the questionnaire ensured that in-depth data that was detailed and explorative of all aspects of the variable(s) under study was obtained. This yielded very useful information for this study and future studies. It also took care of the human nature of the respondent of wanting to express their personal views and feeling important as a participant of the research. This also helped during data interpretation and clarifying numerical data collected.

\subsection{Data Collection Procedures}

The questionnaire was administered electronically. Where this was not possible a hard copy was sent to the respondent. An explanatory letter requesting for the information accompanied the questionnaire. The researcher then communicated to the respondent on the agreed completion date to ask for feed back.

\subsection{Data analysis and presentation}

After all primary data was collected; the researcher classified it in accordance with the variables. Statistical Package for Social Scientists (SPSS) data analysis program was utilized to generate inferential and descriptive statistics: mean, standard deviation, frequencies, charts and percentages from the respondents to establish the relative importance and weight for each of the variables. MS. Excel spreadsheet tools were utilized in presenting the quantitative data. The presentation has been reflected in line and bar charts to depict the relationships and trends between the dependent and independent variables.

\section{CHAPTER FOUR}

\section{DATA ANALYSIS AND INTERPRETATION OF THE RESULTS}

\subsection{Introduction}

This chapter provides answers to the objectives and research questions in chapter one. It also provides new information to add to the existing literature in chapter two. The content is mainly an output of the methodologies outlined in chapter three with explanatory discussions.

\subsubsection{Profile of respondents}

Factors influencing pension managers' investment decisions in Kenya were evaluated using frequency distributions. This chapter reports the analyzed data and results of survey questionnaires. Thirty three top pension managers in eleven pension fund firms participated in the survey as shown in the Table 4. 
Table 4: distribution of respondents

\begin{tabular}{|l|c|}
\hline \multicolumn{1}{|c|}{ Name of pension fund management company } & Number of respondents \\
\hline Stanbic investment services & 3 \\
\hline old mutual asset managers K Ltd & 3 \\
\hline Kenindia asset management & 3 \\
\hline coop trust investment services & 3 \\
\hline ICEA Investments & 3 \\
\hline IAG Global & 3 \\
\hline Madison Asset Management Services & 3 \\
\hline Jubilee & 3 \\
\hline African Alliance & 3 \\
\hline genesis k ltd & 33 \\
\hline Total & \\
\hline
\end{tabular}

\subsection{Quantitative Data Analysis}

\subsubsection{Background Information -fund managers}

Table 5: Respondents Profile by Experience in Fund management

\begin{tabular}{|c|c|c|}
\hline Experience in fund management & Frequency & Percent \\
\hline Above 15 years & 15 & 46 \\
\hline $12-15$ years & 3 & 9 \\
\hline $8-12$ years & 6 & 18 \\
\hline $4-8$ years & 9 & 27 \\
\hline
\end{tabular}

Table 5 shows that majority of the pension fund managers have been in practice for more than 15 years. The data shows that majority of the respondents have attained education above diploma and $1^{\text {st }}$ degree $(64 \%)$ compared to $36 \%$ who had a diploma or a first degree only. This means that most fund managers are staffed with professionals with adequate educational backgrounds. Majority of the respondents were the finance/ business professionals $(64 \%)$ while the rest $(36 \%)$ were educated on investments. The majority $(91 \%)$ were senior and middle level management meaning that they are more likely to be involved in making investment decisions on behalf of the firm customers. Majority (64\%) of the fund managers have been in operation in other financial institutions for 10 years and below. This means that most adhere to the recommendation by Mugweru (2001) that individuals involved in making investment decisions should be professionals with relevant educational and career backgrounds. This also means that the managers have varied experience from different firms.

\subsubsection{Background Information -fund management firms}

Tables 6 shows the frequency distributions of the pension fund managements' background details.

The data shows that majority of the firms have 3 to 6 investment products. This means that the firms have a variety of products for clients to choose from. The data also indicate that majority of the pension fund investment firms deal in group and individual pension fund schemes and unit trusts (equities and treasury bonds).

Majority of the investment management firms had an annual turn over of above Kenya Shillings one billion. This means that they are adequately funded to have diversified portfolios. Absolutely all the pension fund management firms have less than 25 employees which mean that they are likely to have more flat management systems and are less structured. The data shows that corporate bodies/ institutions are the key clients of the pension 
fund management firms. Corporate clients in the pension fund management firms form the highest proportion of between $91-99 \%$ (91\%). This means that these firms are mainly service corporate clients

Table 6: Firms Profile by Number of Products and Clientele

\begin{tabular}{|c|c|c|}
\hline Number of products & Frequency & Percent \\
\hline Above 10 & 2 & 18 \\
\hline $6-10$ & 2 & 64 \\
\hline $3-6$ & 7 & Percent \\
\hline Annual turnover of the firm & Frequency & 93 \\
\hline Above 1 Billion & 8 & 9 \\
\hline 500 Million - 800 Million & 1 & 9 \\
\hline 50 Million - 500 Million & 1 & Percent \\
\hline Below 50 Million & 1 & 9 \\
\hline Proportion of the key clients in the firm & Frequency & 36 \\
\hline $80 \%-90 \%$ & 1 & 55 \\
\hline $91 \%-95 \%$ & 4 & \\
\hline $96 \%-99 \%$ & 6 & \\
\hline
\end{tabular}

Table 7: Company Operations and Systems

\begin{tabular}{|c|c|c|}
\hline How many employees are qualified in Finance/ Business Administration? & Frequency & Percent \\
\hline $1-5$ & 3 & 27 \\
\hline $6-10$ & 6 & 55 \\
\hline $11-15$ & 1 & 9 \\
\hline Over 15 & 1 & 9 \\
\hline Which means of business acquisition does the company use? & Frequency & Percent \\
\hline Direct selling by company staff & 7 & 64 \\
\hline Both direct and use of agents & 4 & 36 \\
\hline Do you pay any commission on business acquisitions? & Frequency & Percent \\
\hline Yes & 4 & 36 \\
\hline No & 7 & 64 \\
\hline What is the income trend from investments? & Frequency & Percent \\
\hline Declining & 3 & 27.3 \\
\hline Stable & 2 & 18.2 \\
\hline
\end{tabular}

The data shows that all the pension fund management firms had computerized their operations. This makes it easy to track access and share market data on investment vehicles and trends thus adding value to the investment decision process. The data shows that majority of the firms had between 6 to 10 employees qualified in Finance/ Business Administration disciplines. This narrows down to an average of 8 employees in 55\% pension fund management firms. Considering the fact that all the firms have less than 25 employees, it implies that in majority of the firms, 8 out of the total number of employees were qualified in Finance and Business Administration disciplines. This is adequate professional staffing level to meet the challenging roles of prudent investment decisions.

Table 7 reflects that the frequency distribution shows that majority of pension fund management firms have adopted direct selling by company staff business acquisition strategy though $36 \%$ have adopted both direct selling and use of agents. The $36 \%$ proportion of firms that use both direct selling and agents acquisition strategies pay commission to the agents. Direct acquisition attracts no commission as the firms argument is that the salary and benefits paid to staff is adequate to the extent of all duties in line with their job descriptions. The data shows that income trends for investments are mainly stable (54.5\%) with more $(27.3 \%)$ indicating a rising trend than a declining one (18.2\%). 
Table 8: Mean return levels on investment funds for year 2004

\begin{tabular}{|c|c|}
\hline List the number of funds, and return for the year $\mathbf{2 0 0 4}$ & Mean return (\%) \\
\hline Pension funds & 9 \\
\hline Investment advisory & 5 \\
\hline T-Bills & 8.6 \\
\hline Segregated funds & 16.5 \\
\hline Unit trusts (Money markets and equity funds) & 81.25 \\
\hline T-Bonds & 9.5 \\
\hline Retail funds management & 22 \\
\hline Trust funds & 7.5 \\
\hline Guaranteed funds & 8 \\
\hline
\end{tabular}

The data in Table 8 shows that unit trusts (Money markets and equity funds) exhibited the highest mean return $(81.25 \%)$ among pension fund investment firms for the year 2004 .

Table 9: Performance/ Growth for the year 2004 relative to the year 2003

\begin{tabular}{|c|c|c|c|c|}
\hline & Paired tests & $\mathbf{t}$ & Df & Sig.(2-T) \\
\hline \multirow{2}{*}{ Pair 1} & What was/is the number of employees in the firm in 2003 & \multirow{2}{*}{-1.6} & \multirow{2}{*}{8} & \multirow{2}{*}{0.15} \\
\hline & What was/is the number of employees in the firm in 2004 & & & \\
\hline \multirow{2}{*}{ Pair 2} & What was/is the assets value for the firm in 2003 & \multirow{2}{*}{-1.3} & \multirow{2}{*}{5} & \multirow{2}{*}{.27} \\
\hline & What was/is the assets value for the firm in 2004 & & & \\
\hline \multirow{2}{*}{ Pair 3} & What was/is the number of clients in the firm in 2003 & \multirow{2}{*}{-1.3} & \multirow{2}{*}{5} & \multirow{2}{*}{.26} \\
\hline & What was/is the number of clients in the firm in 2004 & & & \\
\hline \multirow{2}{*}{ Pair 4} & What was/is your revenues in 2003 & \multirow{2}{*}{-2.8} & \multirow{2}{*}{3} & \multirow{2}{*}{.07} \\
\hline & What was/is your revenues in 2004 & & & \\
\hline
\end{tabular}

Source: researcher's compilation (2005)

In Table 9 the t- test for pairs 1, 2, 3, and 4 with 8, 5, 5, and 3 degrees of freedom have respectively 0.154 , $.265, .257$, and .065 significance. This implies that at $95 \%$ level of significance there was no significant growth in the number of employees, asset value, number of clients, and revenues for the pension fund management companies for the year 2004. This confirms an earlier finding that income trends for investments are stable. However, the revenues in 2003 and 2004 were almost significantly differing.

\subsubsection{Factors Affecting Pension Fund Manager Investment Decisions}

The research sought to find out the fund manger's opinions on the extent to which returns, legal framework, trends of interest rates, decision making preference, investment risks, guaranteed returns, past performance, and investment portfolio affect their choice of investment vehicles.

Rate of Returns: The data shows that returns on investments affect choice of investment vehicles to a very large extent $(82 \%)$ and to a large extent $(18 \%)$. This means that to all fund managers the rate of return is a very important factor. The relationship between return on investment and the investment decision is therefore strongly positive.

Legal frame works: The data shows that Legal frame works affect choice of investment vehicles to some extent $(64 \%)$, to a large extent $(18 \%)$ and to a very large extent $(18 \%)$. This means that the legal framework is not a key factor in investment decision making for pension funds. The relationship between return on investment and the investment decision is therefore weakly positive.

Interest Rates Trends: The respondents were asked to indicate the extent to which Trends of interest rates affect the choice of investment vehicles. The results indicate that this affects the investment decision to a very large extent 
(64\%), to a large extent (18\%) and to some extent (18\%). This means that interest rate trend is an important factor in making investment decision. The relationship with the dependent variable is highly positive. The data shows that trends of interest rates affect choice of investment vehicles to a very large extent

Decision Making Preference: The respondents were asked to indicate the extent to which decision making preference affect the choice of investment vehicles. The results indicate that preference affects the choice of investment vehicle to a very large extent (45\%), to some extent (27\%) and to a small extent (18\%).

The data shows that decision making preference affects choice of investment vehicles to a large extent.

Investment Risks The data shows that investment risks affect choice of investment vehicles to a very large extent $(82 \%)$ and to some extent $(18 \%)$. This indicates a strong positive relationship with the dependent variable.

Guaranteed returns: The data shows that guaranteed returns affect choice of investment vehicles to some extent (46\%), to a small extent (27\%), to a large extent (18\%) and to a very large extent (9\%). Overall guaranteed returns affects choice of investment vehicle to some extent tending to a small extent. This indicates a weak negative relationship with the dependent variable.

Past performance: The respondents were asked to indicate the extent to which Past performance affect your choice of investment vehicles The frequency data shows that past performance affect choice of investment vehicles to some extent $(46 \%)$, to a large extent $(27 \%)$, to a very large extent (18\%) and to a small extent (9\%). This indicates a neutral relationship with the dependent variable that is tending to positive.

Investment portfolio: The respondents were asked to indicate the extent to which investment portfolio affect your choice of investment vehicles. The frequency data shows that investment portfolio affects choice of investment vehicles to a large extent (46\%), to some extent (27\%), to a very large extent $18 \%$ and to a small extent (9\%). The investment portfolio had a positive relationship with the dependent variable.

\subsubsection{Pension Fund Manager Investment Decisions}

Table 10 shows the frequency distribution of the opinion of the fund managers on the most important factors in decision making for pension fund investment

Table 10: Factors in decision making for pension fund investment

\begin{tabular}{|c|c|c|}
\hline $\begin{array}{l}\text { What in your opinion are the most important factors in decision making for pension fund } \\
\text { investment? }\end{array}$ & Frequency & Percent \\
\hline Asset allocation and long term strategy that meets the future liability of the scheme & 3 & 4 \\
\hline Capital preservations/ cash holding & 6 & 8 \\
\hline Consistency and return maximization in the rate of returns/ security, sustainable long term returns & 30 & 42 \\
\hline $\begin{array}{l}\text { Prevailing economic and political situations-inflation, global markets which determines key } \\
\text { indicators like interest rates/ exchange }\end{array}$ & 9 & 13 \\
\hline Balanced portfolio & 3 & 4 \\
\hline risk profile of the scheme investment/ risk assessment of the board of trustees & 9 & 13 \\
\hline liquidity vs. preference & 3 & 4 \\
\hline guarantee maximization & 3 & 4 \\
\hline regulatory framework/ clients discretion/ non discretion & 6 & 8 \\
\hline
\end{tabular}

The data shows that consistency and return maximization in the rate of returns (sustainable long term returns), prevailing economic and political situations-inflation, global markets which determines key indicators like interest rates/ exchange and risk profile of the scheme investment (risk assessment of the board of trustees) in that order are the most important factors in decision making for pension fund investment 
Table 11: Challenges faced by fund managers in making investment decisions

\begin{tabular}{|l|c|c|}
\hline \multicolumn{1}{|c|}{ What are the major problems in investing pension funds? } & Frequency & Percent \\
\hline Capital preservations guarantee & 3 & 6 \\
\hline $\begin{array}{l}\text { Available investments opportunities/ few investment avenues options for investment vehicles/ } \\
\text { markets not deep enough/ lack of wide investment choices/ alternatives }\end{array}$ & 15 & 32 \\
\hline $\begin{array}{l}\text { Bureaucracy- obtaining decisions from trustees cause delays thus interfering with investment } \\
\text { patterns resulting in loss of short lived opportunities/ slow decision making process by the } \\
\text { trustees }\end{array}$ & 12 & 25 \\
\hline diverse un harmonized investment policies and legal frameworks & 3 & \\
\hline $\begin{array}{l}\text { Disruption patterns-retrenchments by the corporate clients resulting in disrupted plans } \\
\text { Un predictable market; turbulent economic situations/ dynamic and constant speculations } \\
\text { based on current research / analysis }\end{array}$ & 3 & 6 \\
\hline Investment ceiling/ smaller asset classes in the RBA Act & 6 & 6 \\
\hline transaction costs & 3 & 6 \\
\hline
\end{tabular}

In Table 11 the data shows that few investment avenues/ vehicles, bureaucracy resulting from consultations with trustees and unpredictable/ turbulent $\&$ dynamic market situations in that order are the major problems facing fund managers investing pension funds

\section{Impact of RBA on the role of fund managers}

The research asked the question, what if any are the impacts of Retirement Benefit Act on your role as a fund manager? Most responses (12) indicated that Regulatory environment bring order and discipline in the management of pension funds- protect retirement benefit funds/ improved sponsor contributions thus values are growing faster. This was followed by those (9) who felt that RBA is a spring board for pension fund investments as it creates a level play ground for all players by giving quarterly market information with regards disclosure on performance-asset values, closing prices, rates of returns etc calendar updates, competition, lobbying and gives guidelines. However, a few had negative sentiments especially in relation to limited investment opportunities as a result e.g. the restriction of offshore investments.

The data shows that the major impacts of RBA are in the legal perspective that has restored order and discipline in the management of pension funds. The result has been the protection retirement benefit funds from employer thus improving sponsor contributions. The frame work has also given a structured investment guidelines. These guidelines have both sides of the comparative advantage/ disadvantage in the sense that fund managers are protected from blame with regards to lost opportunities in a given investment vehicle resulting from lower asset value class. But at the same time, ceilings on investments results in limited investment opportunities offshore investment is restricted. Also the RBA has created a spring board for pension fund investments as it creates a level play ground for all players by giving quarterly market information with regards disclosure on performance-asset values, closing prices, rates of returns etc calendar updates, competition and lobbying. include:

Other laws governing the operations of Pension fund managers. These laws according to the findings

- $\quad$ Capital Markets Authority-tax regulations on returns
- $\quad$ Trustees Act
- $\quad$ Profurance Act- Commissioner of Insurance
- $\quad$ KRA Act code of ethics
Company's Act




\section{Pension investment in Kenya versus other countries}

The respondent was asked how pension investment in Kenya compares with other countries. As Figure 2 reflects, the majority of the responses indicate that pension investment in Kenya is still in its infancy stage following the introduction of the RBA Regulations in 2000. Markets are just starting to open up as management of pension scheme are removed from the control of the employers and transfer of pension portfolio when an employee shifts employment. The market therefore is not well developed as a result of limited investment vehicles/ smaller market due to a few number of investment products compared to the developed world. However some felt that regionally we are ahead, regionally, we are ahead. Some responses were as follows:

- $\quad$ "a long way to go as there are still hiccups in management and coordination of the pension investment sub industry"

- $\quad$ "Less information available to pension fund managers e.g. research on equities and money markets than in the developed world"

- "Not very well developed especially in the informal sector"

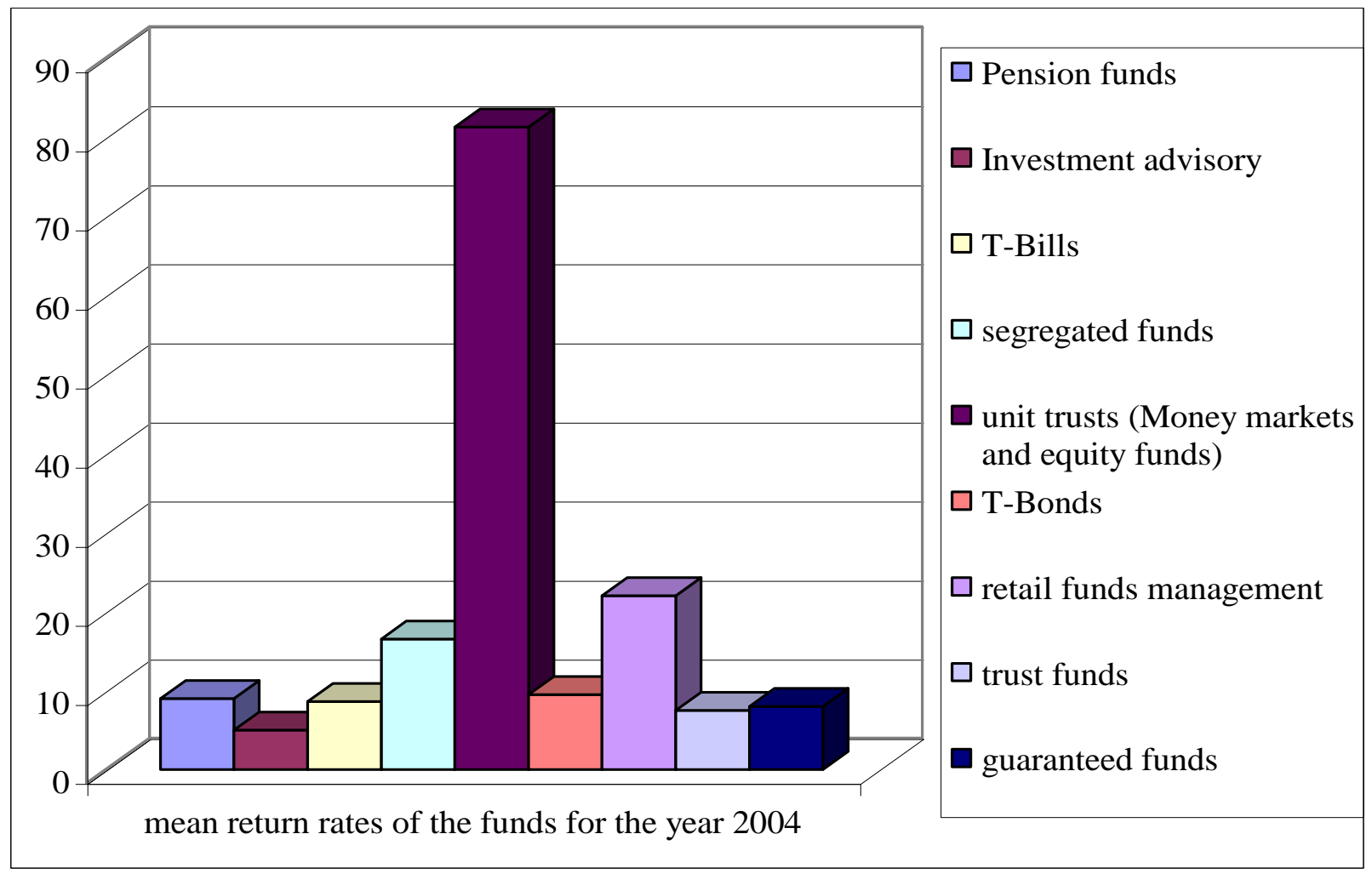

Figure 2: mean fund investment trends for the year 2004

\section{Suggestions For Improvement}

In order to elicit suggestions on policy issues relating to pension funds the research posed the question, If your the finance minister, what recommendations would you make to improve the management of pension funds in the country?

The responses indicate that one of the most burning issue is the limit on off shore investment (15\% ceiling) which was considered too low by over half of those who responded to this question. This will create the potential of 
portfolios earning a higher return with an example given of Singapore. The other issue was in relation to harmonization of all Acts relating to pension fund which include RBA, KRA and the Trustee Act.

For example the RBA act says that in circumstances where the RBA is in conflict with any other law, the RBA supercedes. The RBA is silent on the a clause on the trustees act stating that you cannot buy shares of a quoted company that has not paid dividend to the shareholders for the past five years. Tax exemption for a pension scheme is wavered at the KRA and registration at the RBA. A suggestion was given to consolidate all the operations of pension schemes with the RBA.

\section{CHAPTER FIVE}

\section{SUMMARY OF FINDINGS, CONCLUSIONS AND RECOMMENDATIONS}

\subsection{Introduction}

This Chapter addresses the findings of the Study in relation to the objectives outlined in Chapter one. It also highlights the limitations of the work and suggestions for further research.

\subsection{Discussions and Conclusions}

The Study established that the factors that affect pension managers investment decisions were rated as follows in the order of importance. Returns and investment risks, trends in interest rates, decision-making preferences, investment portfolio, past performance and legal framework. Consistency and return maximization in the rate of returns (sustainable long term returns), prevailing economic and political situations-inflation, global markets which determines key indicators like interest rates/ exchange and risk profile of the scheme investment (risk assessment of the board of trustees) in that order are the most the most important factors in decision making for pension fund investment. It appears that the operating environment largely influences fund managers both from a local and global perspectives. Stakeholder interests and sentiments are also considered in making investment decisions.

The research also found out that few investment avenues/ vehicles, bureaucracy resulting from consultations with trustees and unpredictable/ turbulent and dynamic market situations in that order are the major challenges facing fund managers investing pension funds. The legal framework also set ceiling for certain investment classes that may be limiting. The $15 \%$ limit on overseas investments maybe a stumbling block in achieving higher returns.

\subsection{Recommendations}

The researcher arrived at the following recommendations. There is need for a portfolio that will give higher returns. On this note RBA needs to regularly study the market and adjust the set limits to reflect the prevailing market conditions. There is also need to regulate all regulations relating to pensions in order to create efficiency and avoid confusion.

RBA also needs to benchmark with the world best and perfect the best practices in order to help the sector to achieve growth. More focus should be on promotion of retirement funds and not regulation. Too much focus on regulation can hinder growth of the sector. It would be appropriate for RBA to separate its regulatory and promotion roles i.e. allocate different staffs to each. There is a conflict of interest in the two roles as regulatory role is for enforcing the rules, which tends to highlight the negatives and as a result can create credibility issues. While promotion focuses on the positive angle which is a credibility builder.

\subsection{Limitations of the Study}

It was not possible to have a one-on-one interview with the respondents. A number of respondents expressed the desire to give more insight to their views if this was possible. 
There was also a constraint of availability of respondents through human engagements such as leave of absence, training, or overseas engagements. Nonetheless, the researcher managed to get response from all respondents meaning that that these limitations had marginal effects on the overall findings of the Study.

It was also appreciated that respondents bias may have been an inevitable part of the Study as fund management employees were required to make a judgement on the institution that they work for. This was, however, minimised by encouraging anonymous responses.

\subsection{Suggestion for Further Research}

The research was quantitative in nature, to a certain degree, as it identified the aggregate position of the situation without interrogating the quality of individual responses through interviews. A qualitative case study could be conducted in future to dwell deeper into the reasons behind how and why fund managers make investment decisions as identified in this research. The opinions of the customers especially the trustees, contributors and pensioners may also be sought in future.

\section{DEDICATION}

I wish to dedicate this work to God and my family

\section{ACKNOWLEDGEMENT}

I wish to thank my supervisors for the professional and dedicated guidance they have been offering during the writing of this project

\section{REFERENCES}

1. Appleby, R. C. (1994); Modern Business Administration

2. Commissioner of insurance circular No. CI/01/02, Government Printers, Nairobi

3. Commissioner of Insurance Circular No. C1/01/02, Government Printers, Nairobi

4. Coomber, K, (2003); Professional pension: specialist investment managers

5. Deloitte and Touche, (2004); Strategic Risk Management, Deloitte and Touche Insight April 2004 Issue, Nairobi

6. Fortune (2004); Investors Guide 2004, Cover Story, Fortune Magazine, Europe Edition, January 2004

7. Grubel, S and Fadner, R (1971); The interdependence of International Equity Market, Journal of Finance, March 1971 pp 89-94

8. $\quad$ Insurance Act Chapter 487 (2004), Government Printers

9. Kiptanui (2003); A new Dawn in Retirement Benefits $19^{\text {th }}$ Trustee Training Seminar, April $25^{\text {th }} 2003$, Unpublished Seminar material

10. Kluwer (1996); Handbook on pensions, Kluwer and Crooner Publishing Limited,London

11. Mogera S (1999): Planning for retirement, (A case of the university of Nairobi staff), Unpublished MBA project, University of Nairobi

12. Marwa S.M. (1992): Actuarial costing methods used in insured pension schemes in Kenya, Unpublished MBA Project, University of Nairobi

13. Mghali F (2003); Employee Pension and its effects: A case of Combrok Limited. Mombasa, MBA Thesis University of Nairobi

14. MicroSave-Africa (2000); Savings In Africa, A Collection of Studies from MicroSave- Africa, UNDP/DFID Initiative

15. Mugenda A G, Mugenda O M (1999); Research Methods, Quantitaive and Qualitative Approaches, ACTS Press, Nairobi

16. Mugweru T W (2001); Factors affecting the efficiency of the national provident funds in Kenya: A case of National Social Security Fund, Unpublished MBA Thesis, University Of Nairobi

17. RBA Annual Report (2003), Chairman's Statement, Annual Report, July 2002-2003 
18. RBA NEWS (2002); Survey Reveal Lack of Private Sector Pensioners, Quarterly News Letter of the Retirement Benefits Authority Vol. 1. No. 3 March 2002

19. Saunders M.,Lewis P., Thornhill A.,(2003); Research Methods for Business Students Rotolito Lumbards, Italy

20. url; www.pensioworld.co.ke may 2003 Investments Survey Results

\section{NOTES}


NOTES 